\title{
PUBLICISTIČNI \\ IN KRITIŠKI SLOG PAVLA ŠIVICA V GLASBENI MLADINI $(1974-1995)^{1}$
}

Glasbena revialna literatura je imela $v$ sedemdesetih letih kar nekaj zgledov, katerih dejavnost pa je bila razmeroma ozka. Glasbena mladina (GM) je s svojim konceptom zapolnila nekaj manjkajočih vrzeli, saj sta bila njen načrt in vsebina splošnejša. ${ }^{2}$ Revija naj bi pokrivala raznovrstne glasbene teme in poročala o vsestranskem glasbenem življenju v Sloveniji, intenzivno pa se je s svojo dejavnostjo vključevala tudi v tuje glasbeno dogajanje.

V glasbeno publicistično delovanje organizacije Glasbena mladina Slovenije (GMS) se je Pavel Šivic vključil že v sezoni 1974/75 in s svojimi prispevki sodeloval v njej dvajset let, vse do svoje smrti. V reviji je objavil okoli 130 prispevkov, od tega največ kritik in poročil o koncertih in opernih predstavah, recenzij plošč in knjig, poleg tega pa še ocene koncertnih sezon in biografske prispevke v obliki spominov, nekaj pedagoških člankov in prevodov. Število prispevkov je veliko, vendar pa je to samo del Šivičevega publicističnega opusa, ki ga pokrivajo tudi druge revije in časopisi. ${ }^{3}$

Pretežni del Šivičevih prispevkov v GM predstavljajo kritike. Med njimi je nekaj poročil v strogo publicističnem smislu: po obsegu so to kratki prispevki, s pretežno faktografsko vsebino, le tu pa tam je pisec $s$ posameznimi besedami

\footnotetext{
1 Vsebina prispevka je povzeta po diplomski nalogi, ki je nastala pod mentorstvom prof. dr. Katarine Bedina na Oddelku za muzikologijo Filozofske fakultete v Ljubljani.

2 Idejni pobudnik za nastanek revije je bila organizacija Glasbena mladina Slovenije, katere prvi občni zbor in s tem tudi ustanovitev je bila leta 1969. Prva, poskusna številka Glasbene mladine je izšla maja 1970 in je bila že od samega začetka deležna velikega zanimanja. Njen prvi letnik datira v sezono $1970 / 71$. Do sezone $1976 / 77$ je izhajala v šestih številkah, dve sezoni v sedmih, od sezone $1978 / 79$ pa v osmih.

3 V letih 1937 do 1995 je Šivic najpogosteje objavljal v naslednjih časopisih in revijah: Delo, Glasbeni list Opera - balet, Glasbena mladina, Grlica, Jutro, Ljudska pravica, Naši razgledi, Naši zbori, Slovenski poročevalec, Slovenska glasbena revija.
} 
nakazal vrednostno oceno koncerta. Vendar pa je taka, okleščena oblika prispevka pri njem precej redka, saj se v večini primerov ni mogel izogniti ocenjevanju. Tudi za kritike velja, da niso vedno ustrezale svojemu publicističnemu namenu. Tako se je pogosto spustil na raven poročila, ob tem pa le bežno dodal svojo oceno. Večkrat ga je k temu napeljala osebna naklonjenost bolj sodobno zasnovanim koncertnim sporedom kot pa klasično. Pogosto je Šivičeva kritika dosegla svojo najvišjo instanco in namen - le kot posledica take izvedbene ravni, v kateri je bil "vsak skladatelj predstavljen v polni luči svojih umetniških značilnosti in osebnega izraza".4

Šivičeve kritike predstav ljubljanske Opere v GM niso izšle v tako velikem številu kot kritike koncertov, predvsem pa niso izhajale kontinuirano; od celotnega, dvajsetletnega sodelovanja $z$ GM so bile objavljene le v devetih letnikih. Medtem ko je koncerte ocenjeval $\mathrm{z}$ opisnega vidika, je njegov koncept kritik opernih predstav precej drugačen. Razlika ni samo v tem, da so te kritike obsežnejše, ampak tudi v tem, da je pisec veliko pozornosti namenil opisu operne zgodbe in njeni zgodovinski umestitvi. Gre torej za kritiško ožji, glasbeno pa širši koncept. Ko primerjamo ocene opernih solistov s koncertnimi, ugotovimo, da so slednje izčrpnejše in dajejo bralcu veliko več neposrednosti. Ponavadi je interpretacije opisal z izrazi, kot so "psihološko plemenita igra", "zlitost nastopajočih v soigri", 6 "predstava je bila v tem pogledu na dopadljivi ravni". ${ }^{7}$

Iz podrobnejše primerjave ugotovimo, da je Šivic zavestno izvzel pravo vrednostno ocenjevanje, prav tako pa tudi kritičnen odnos do zunajglasbenih problemov. Tako na primer o stanju ljubljanske Opere kot institucije v njegovih člankih ne najdemo nobenega komentarja. Le $\mathrm{v}$ enem primeru je $\mathrm{v}$ predstavi pogrešal igralsko doživetost in "za rast tega občutka bi bila potrebna stalna navzočnost sposobnega opernega režiserja skozi vso sezono. Žal ga ni!" ${ }^{8}$ Tudi do izvedbene ravni opernih predstav ni bil, razen $\mathrm{v}$ dveh primerih, posebno kritičen. Tako mu je premiera Jevgenija Onjegina vzbudila dvom, "da ljubljanska [O]pera trenutno premore tisto žlahtnost muziciranja, ki smo ga znova in znova občudovali na našem odru pred vojno in po njej," premiera Wertherja pa se mu je zdela glasbeno neupravičena, saj je bila izvedba "še vedno preračunana na ganljivost situacije in ploskanje petju ob najmanj primernih trenutkih, torej rajši 'show' kot dramatično napet lok". ${ }^{10}$

4 Gl.: GM 8 (1977/78) št. 2, str. 5.

5 Gl.: Bela Bartok: Grad vojvode Sinjebradca. GM 10 (1979/80) št. 5, str. 7.

6 Gl.: Nova predstava v ljubljanski operi. GM $10(1979 / 80)$ št. 7, str. 6.

7 Gl.: Mozartova Čarobna piščal spet na odru ljubljanske Opere. GM 13 (1982/83) št. 5, str. 11.

8 Gl.: Nova predstava v ljubljanski operi. GM 10 (1979/80) št. 7, str. 6.

9 Gl.: "Onjegin" spet v Ljubljani. GM 8 (1977/78) št. 7, str. 7.

10 Gl.: Ljubljana: Werther. GM $9(1978 / 88)$ št. 3, str. 15. 
Takšne, redke kritične pripombe presenečajo, saj je bil Šivic do glasbenega in siceršnjega stanja $\mathrm{v}$ operi precej popustljiv.

Povsem drugačen je Šivičev pristop k ocenjevanju programa Festivala Ljubljana ${ }^{11}$ in ljubljanske koncertne ponudbe nasploh. Medtem ko so prispevki o ljubljanskih opernih predstavah bolj opisi kot kritike, pa se nam druge ocene kažejo v povsem drugačni podobi. V ocenjevanju se je Šivic ne glede na osebne preference vedno osredotočil samo na ustvarjalnost in poustvarjalnost. Izjemen primer, kjer ga nista zanimala le ta dva dejavnika, je bil ljubljanski poletni Festival, ki mu je - ne le kot prireditev, temveč tudi kot institucija - vzbudil toliko pomislekov in vprašanj, da je svoj kritičen odnos v veliki meri preusmeril na druge, zunajglasbene dejavnike. Med pomanjkljivostmi, ki jih je očital ljubljanskemu Festivalu, je bila neopredeljena programska usmeritev. Tako je že za sezono 1983 zapisal, da "ljubljanski festival nima kake vnaprej določene umetniške usmeritve,"12 navzočnost problema pa je dosegla višek v kritiki za sezono 1987, ko se je Šivic kar nekoliko drzno spraševal o eksistenčni upravičenosti Festivala, ki "svojega lastnega umetniškega profila še vedno ne more najti". ${ }^{13}$ Vzrok za tako ostre trditve je potrebno iskati v nenehnih dvojnostih festivalske dejavnosti, saj prireditve niso bile usklajene niti programsko niti kvalitativno.

Poleg takih in podobnih odklonilnih ocen najdemo še številne druge, kjer je bil pisec upravičeno kritičen. Kot dober poznavalec celoletnega ljubljanskega glasbenega dogajanja je npr. opozoril, da "ni prijetno, če se dela, ki jih že med letom redno slišimo, v festivalskem sporedu po večkrat ponavljajo" ${ }^{14}$ Istočasno je bil kritičen tudi do sporeda, saj so po njegovem "dobro obiskane predvsem tiste manifestacije, ki skrbijo za show in zabavo". ${ }^{15}$ Kot kritik je moral nujno opozarjati na pomankljivosti in napake Festivala, ki naj bi enakovredno kot tudi druge glasbene institucije skrbel za drugačen profil poslušalcev, dolžan je zapoljnjevati programske šibkosti siceršnje kulturne in glasbene ponudbe. Upravičeno je Festivalu očital nedosledno programsko politiko, ki se je odražala $v$ njegovi programski ponudbi.

Šivičeve ocene ljubljanskih festivalskih prireditev in ob tem še treh ljubljanskih glasbenih sezon ${ }^{16}$ so zanimive tudi s sociološkega vidika; ta ni $\mathrm{v}$ nobeni drugi tematiki tako izrazit in stalno prisoten. Opozoril je na festivalsko publiko, katere okus se niža iz leta v leto in je "vedno manj tistih, ki se tudi v poletnem času radi

11 V sezonah 1983, 1985, 1987, 1988 in 1989.

12 Gl.: Trideset poletij. GM 13 (1982/83) št. 1, str. 8-9.

13 Gl.: Poletni festival križanke. GM 17 (1986/87) št. 1, str. 2 - 3.

14 Gl.: ibid.

15 Gl.: Odmevi z mednarodnega festivala Ljubljana. GM 18 (1987/88) št. 1, str. 2.

16 V sezonah 1979/80, 1989/90 in 1993/94. 
poglabljajo v duhovne vrednote" ${ }^{17}$ Ta problematika ga je spodbodla v taki meri, da je objavil prispevek, namenjen izključno temi koncertnega občinstva. ${ }^{18}$ Opazoval je različne ravni poslušalcev, ki so s pasivnostjo in nekritičnostjo "sledili $\mathrm{v}$ glavnem zvočnim učinkom, ne da bi jih skušali povezati $\mathrm{v}$ [...] umetniško sporočilo." ${ }^{19}$ Zato se je upravičeno spraševal, "ali bo kdaj prišlo do zbliževanja okusov". ${ }^{20}$

Razumljivo je, da se v tej problematiki nenehno prepletata dva dejavnika: občinstvo in programska politika neke glasbene institucije. Ko je Šivic operni publiki očital zastarel okus, koncertni pa meščanskost, se je seveda zavedal, da sta publika in koncertni program v soodvisnosti. Prav tako pa je stopnja komercialnosti programske ponudbe in deleža skladb, ki "vedno ogrejejo", ${ }^{21}$ odvisna od pričakovanj in zahtev večinskega poslušalstva. V zaključku istega prispevka je v njegovi želji, da bi poslušalci "hrepeneli za dobro, zanimivo, vredno in tudi sodobnejšo glasbo", čutiti nemoč proti ustaljenemu toku programske politike glasbenih institucij. Dejansko se je idejno strinjal le z dejavnostjo Društva slovenskih skladateljev, ki je najbolj celovito izpolnilo njegova umetniška, izvajalska in programska pričakovanja nekega glasbenega dogajanja.

$\mathrm{Na}$ tem mestu bi se bilo primerno vprašati, zakaj se ocene opernih predstav in festivalskih koncertov po vsebini tako razlikujejo. Zakaj Šivica pri tako vsestranskem razmišljanju in ocenjevanju festivalskih koncertov niso zanimala sociološka, programska, akustična - torej glasbeno sekundarna vprašanja - tudi v okviru ljubljanske Opere in zakaj se je nanje najpogosteje obračal prav v primeru Festivala Ljubljana? Njegova misel, da bi morali biti oblikovalci koncertnega programa "skrbno izbrani umetniški sosveti", je sicer dobra, vendar preveč utopična, saj ji je istočasno oporekal, češ da "praksa tega vedno ne potrjuje". ${ }^{22}$ Zanimivo se torej zdi, da je te dejavnike v najmanjši meri oziroma jih sploh ni upošteval v kritikah opernih predstav. Težko bi bilo trditi, da ob obiskovanju predstav v ljubljanski Operi in celo abonmajskih koncertov SF in RTV Ljubljana ne bi mogel naleteti na vprašanja, ki bi se zdela za te glasbene institucije celo bolj primerna. Nemara je razlog v tem, da je Šivic poznal produkcijo ljubljanske Opere v njenih najboljših časih in bil z njenim nazadovanjem sprijaznjen do te mere, da se je namenoma izogibal polemičnim vprašanjem in kritikam institucije ter njeni izvajalski ravni.

17 Gl.: Odmevi z mednarodnega festivala Ljubljana. GM 18 (1987/88) št. 1, str. 2.18 Prim.: O koncertnem občinstvu. GM 24 (1993/94) št. 6, str. 3 .

19 Gl.: O koncertnem občinstvu. GM 24 (1993/94) št. 6, str. 3.

20 Gl.: ibid.

21 Gl.: Ljubljanski koncertni abonmaji. GM 20 (1989/90) št. 13, str. 3.

22 Gl.: Obeti ljubljanske glasbene sezone. GM 10 (1979/80) št. 2, str. 3. 
Pomemben delež Šivičevih prispevkov v GM predstavljajo poleg kritik tudi recenzije plošč. Kljub temu, da osebno ni bil navdušen poslušalec plošč, pa je na spodbudo odbora GMS napisal petintrideset recenzij plošč in skoraj izključno sam vseh dvajset let pri GM zapoljnjeval rubriko z ocenami plošč domače produkcije. Podobno kot pri drugih publicističnih zvrsteh zaznamo tudi pri številnih recenzijah Šivičevo pristranskost, ki izhaja iz njegove osebne naravnanosti k sodobnemu. Vsebina recenziranih plošč so pretežno sodobne skladbe, redkeje tradicionalne. Do slednjih je imel bolj površinski odnos, v ocenjevanju sodobnih del pa je izkoristil priložnost, da je izrazil osebno glasbeno usmeritev. Zanimiva je primerjava recenzij Pollinijeve plošče in Lebičeve zgoščenke Queensland Music. Siceršnje navdušenje nad slogovnim in kompozicijskim značajem je $\mathrm{v}$ prvi recenziji skrčil na nekaj besed, preostalo pozornost pa namenil prav tako pomembni zgodovinski razlagi. Druga recenzija pa prav nasprotno potrjuje Šivičev značilni entuziazem, ki je odraz ne le skladateljskega, temveč tudi estetskega premisleka. V znatno manjšem številu so recenzije plošče $s$ komercialnim in žanrsko vprašljivim sporedom - z nizom zborovske pesmi za razne sestave, "od umetniško tehtne do zabavne 'aufbiksarske' " ${ }^{23}$ Do takih je Šivic pokazal znatno mero brezbrižnosti in celo ironije, saj so te plošče "dobrodošle za proslave vseh vrst", ${ }^{24}$ izvajalcem pa je le uvidevno priznal, da se " $z$ navdušenjem in požrtvovalnostjo trudijo za lepo skupinsko petje". 25

Knjige, za katere je Šivic napisal recenzije v GM, ${ }^{26}$ so različnih tematik, vendar pa je bil zaradi svoje razgledanosti in široke dejavnosti kompetenten kot recenzent tudi teh. Kljub vestnosti, ki jo Šivicu na splošno lahko pripišemo, pa ugotovimo znatne razlike med recenzijami plošč in recenzijami knjig. Očitno je, da se je pisec bolje znašel v glasbeno izvajalski snovi kot pa v publicistični.

Poleg posameznih prispevkov predstavljata tako po obsegu kot po vsebini pomemben delež v Šivičevem publicističnem opusu v GM dva tematska sklopa: prvi z naslovom Spomini na sodobnike je izhajal v sezoni 1981/82, drugi - Glasba XX. stoletja pa v sezoni 1986/87. Prvi tematski sklop in še nekaj posameznih prispevkov iz poznejših let je nekakšna antologija spominov na glasbenike, ${ }^{27} \mathrm{ki}$ so bili v zgodovinskem duhu sicer še prisotni, v osemdestetih letih pa vendar že oddaljeni od glasbene sedanjosti. Niz spominov je Šivic napisal na zunanjo pobudo $z$

23 Gl.: GM 8 (1977/78) št. 4, str. $16-17$.

24 Gl.: ibid.

25 Gl.: ibid.

26 A. Trstenjak: Psihologija ustvarjalnosti; J. Gregorc: Moje izkušnje in pogled na zborovodstvo; A. Rubinstein: Mojih mnogo let I; C. Budkovič: Razvoj glasbenega šolstva pri Slovencih; E. Maynell: J. S. Bach, Mala kronika Ane Magdalene Bach.

27 Večina spominov je nastala v sezoni 1981/82 in deloma v naslednji. Trije prispevki - o Janku Ravniku, Carlu Orffu in Rafaelu Ajlecu so nastali kot nekrologi. Iz kasnejših sezon GM sta zanimiva še dva prispevka: Spomini na predvojno Prago in Spomini na mlada leta ljubljanskega radia. 
namenom, da bi se v prihodnosti ohranilo vsaj nekaj živih pričevanj. Žal pa se je omejil le na starejšo generacijo in ni posredoval spominov na sodobnike svoje generacije.

Spomini so žive pripovedi, v katerih se prepletajo na eni strani objektivna spoznanja in na drugi subjektivni vtisi o sodobnikih in se s tem bistveno oddaljujejo od skopih biografskih orisov. Prispevki o Slavku Ostercu, Josefu Suku, Aloisu Habi, Antonu Lajovicu, Lucijanu Mariji Škerjancu, Marjanu Kozini, Carlu Orffu, Juliju Betettu, Antonu Trostu, Mateju Hubadu, Janku Ravniku, Jožetu Gostiču, Karlu Ruplu in Marti Valjalo se zdijo kot raznolika, nepovezana skupina glasbenih umetnikov dveh generacij. Pa vendar so ti ustvarjalci in poustvarjalci, bodisi usmerjeni $\mathrm{v}$ pedagoško bodisi $\mathrm{v}$ poustvarjalno delo, kot učitelji ali kot njihovi učenci predstavljali "stebre naše glasbene kulture". ${ }^{28}$ Ta niz spominov je pomemben doprinos $\mathrm{k}$ poznavanju slovenske glasbene zgodovine, ki je prav $\mathrm{s}$ temi ustvarjalci dobila prvo akademsko izobraženo generacijo. V Spominih zaznamo Šivičev objektivni pristop do biografske, zgodovinske snovi, prav tako pa predstavo o njegovem nazoru ter glasbeno slogovnem in estetskem prepričanju. Ovrednotil je umetniško vlogo posameznika in mu priznal pomen v slovenski glasbeni kulturi; vse to pa obogatil $s$ pestrim pripovedovanjem o osebnih srečanjih $z$ glasbeniki. Prav ta plastičnost daje prispevkom edinstveno možnost zgodovinskega predstavljanja.

Kljub piščevi nepristranskosti je prav njegov odnos do snovi to, kar priča o njegovih osebnih stališčih do različnih smeri sodobne glasbe in različnih glasbenih dejavnosti. Osebna nota Šivičevih Spominov je namreč tako močna, da dejavnost enega umetnika izzveni bolj biografsko, skoraj neopazno, dejavnost drugega pa kot bogata refleksija. Pri snovi se je potrebno od vsebine prispevkov oddaljiti vsaj $\mathrm{v}$ tolikšni meri, da lahko razberemo piščevo pristranskost in jo pripišemo njegovi osebni nagnjenosti, ki jo je gojil do nekaterih dejavnosti. Največ entuziazma je vnesel v prispevke o glasbenikih - skladateljih, s čimer je posredno lahko zagovarjal svoja stališča do sodobnosti. Tako npr. govori o Slavku Ostercu kot zagovorniku sodobne glasbe in o njegovi "naperjenosti zoper romantizem ali celo sentimentalnost v vsakdanjem življenju". ${ }^{29}$ Pričakovali bi, da je bil Šivic kot Osterčev učenec ne samo nadaljevalec njegove kompozicijske usmeritve, ampak tudi njegov idejni pristaš. Vendar pa idejno dvojnost njunih estetskih vidikov zelo jasno potrjuje Šivičeva izjava, da se mu je šele ob Hindemithovi glasbi "razodelo, koliko muzikalnosti je možno vložiti v tak izventonalni slog". ${ }^{30}$ Za Osterca je trdil, da "ni verjel $\mathrm{v}$ intimnost glasbene izpovedi [...]. Odpor do sentimentalnega življenja in

28 Gl.: Spomini na Jožeta Gostiča. GM 14 (1983/84) št. 3, str. 11.

$29 \mathrm{Gl}$.: Mojster orkestralne in komorne glasbe. GM 12 (1981/82) št. 1, str. 14.

30 Gl.: ibid. 
izživljanja mu je bil po naravi tuj." ${ }^{31}$ Osterčev estetski vidik glasbe se nam zdi v tem zapisu zanimiv kot zgodovinsko dejstvo, pa vendar iz Šivičevih artikuliranih komentarjev razberemo prav nasprotno, saj mu je bila pomembnejša muzikalna, glasbenoizpovedna vrednost kompozicijskega dela. To je še konkretneje potrdil v spominih na Josefa Suka. Z njegovo romantično skladateljsko usmeritvijo in navdušenjem nad "prijetnimi zaporednimi sekstami" 32 se resda ni strinjal, vendar se vanju ni poglabljal. Poudaril je to, kar je pogrešal pri Ostercu, torej "intimno skladateljsko izpoved" ter "ganljivost in pristnost te glasbene izpovedi, ki jo je narekovala globoko čuteča duša". ${ }^{33}$ Med osrednjmi značilnostmi, ki je pritegnila Šivičevo pozornost, je torej posameznikov odnos do sodobne glasbe, četudi odklonilen. Še izraziteje kot v prispevku o Antonu Lajovicu se Šivičev odklonilni odnos do romantizma pokaže v spominih na Lucijana Marijo Škerjanca. Že v prepričanju, da se je "piščeva življenjska pot pogosto neprijetno križala z njegovimi nazori", ${ }^{34}$ vidimo razhajanje njunih usmeritev: Šivičeve radikalne in Škerjančeve romantične, konservativne ter odklonilne do "sodobnih kompozicijskih iskanj". ${ }^{35}$

Manj polemičnega navdušenja razberemo iz Šivičevih spominov na tiste glasbenike, katerih dejavnost je bila usmerjena $\mathrm{v}$ poustvarjalni ali pedagoški poklic. Tako na primer v spominih na neskladateljsko dejavnost Antona Lajovica ne zaznamo tiste siceršnje osebne note ne glede na znatno mero spoštljivosti. Šivic je Lajovicu sicer priznal široko razgledanost, zavzetost in zasluge za slovensko in slovansko glasbo, pa vendar se v pripovedi kaže prikrita zadržanost, ki se na mestih sprevrže celo v kritičnost do te "sive eminence našega glasbenega življenja". ${ }^{36} \mathrm{~V}$ obdobju, ko se je zgodovinsko utemeljevala slovenska glasbena umetnost in zavest, so bili Lajovčevi pogledi nujni in razumljivi. Vendar je Šivic - kot zagovornik novega in naprednega - v povojnem obdobju razumel Lajovčevo monopolno intelektualno in duhovno prisotnost $\mathrm{v}$ slovenskem glasbenem prostoru kot konservativno. $\mathrm{V}$ sicer lepem in spoštljivem besednem slogu je zaključil prispevek $\mathrm{s}$ pripombo, da je povojno obdobje "Lajovicu kot zaslužnemu umetniku in dolgoletnemu vidnemu kulturnemu politiku marsikateri greh prostodušno odpustilo". ${ }^{37}$

Opazno manjšo mero kritičnosti in osebnega pristopa je Šivic vnesel v spomine na slovenske poustvarjalce - interprete. Čeprav je bil tudi sam izvajalec, je ob teh biografskih opisih imel že manj iztočnic, s katerimi je lahko nakazal osebne nazore.

31 Gl.: ibid.32 Gl.: Josef Suk - kar preveč potisnjen v pozabo. GM 12 (1981/82) št.2, str. 15.

$33 \mathrm{Gl}$ : ibid.

34 Gl.: L. M. Škerjanc - skladatelj in kritik. GM 12 (1982/82) št. 5, str. 16.

$35 \mathrm{Gl}$ : ibid.

36 Gl.: Anton Lajovic - skladatelj in pravnik. GM 12 (1981/82) št.4, str. 14.

37 Gl.: ibid. 
Zato je $\mathrm{v}$ večji meri opisoval njihove značajske poteze in svoja srečanja $\mathrm{z}$ njimi. Zapisi o interpretacijskih in umetniških vrednostih so redki. Poustvarjalcem je lažje kot skladateljem priznal umetniške zasluge za slovensko glasbo, tudi zato, ker se je večina med njimi udejstvovala $v$ tujini in manj na Slovenskem. Šivic je vse glasbenike ocenjeval $z$ vidika sodobnika in razumljivo je, da tudi glasbeni poustvarjalci niso ušli tej vrsti presoje. Tako je npr. za Antona Trosta pohvalno zapisal, da se "ni branil sodobnejših skladb", ${ }^{38}$ za Julija Betetta, da je v münchenski operi pel v četrttonski operi Matka Alojza Habe, kar je veljalo za veliko avantgardno glasbeno senzacijo Šivičevih študentskih let. Z nekakšno užaljenostjo glasbenega sodobnika pa je dodal tudi to, da se je Betettu zdela višek slovenskega samospeva Pavčičeva Žanjica. Prav nasprotno pa je Janku Ravniku priznal širino in nepristranskost duha, saj kljub temu, da je bil "dedič slovenske nove romantike, [...] ni nikoli negodoval, če smo študentje grabili po delih skladateljev, ki so tedaj veljali za avantgardo" ${ }^{39}$ Zanimivo je, da je bil Šivic kot naslednik generacije sodobnikov sicer spoštljiv, vendar pa izjemno kritičen. Ne glede na to, da so njegovi Spomini nastali v precejšnji zgodovinski odmaknjenosti, pa je bil strog do posameznikovih nesodobnih nazorov, ki so se mu zdeli v novem zgodovinskem, drugačnem umetniškem povojnem obdobju ne le odvečni, temveč tudi škodljivi in neprimerni.

Posebno mesto $\mathrm{v}$ prispevkih zavzemajo pričevanja o sodobni glasbi, ki je prisotna tako $\mathrm{v}$ kritikah, recenzijah, poročilih kot tudi $\mathrm{v}$ biografskih, pedagoških in zgodovinskih prispevkih, torej povsod, ne glede na publicistično zvrst. Za to temo lahko rečemo, da je stalnica Šivičeve publicistike in odraz njegove kontemplativne narave. Tako je v sezoni 1986/87 v GM objavil sedem prispevkov z naslovom Glasba XX. stoletja. Namen prispevkov je bil primarno pedagoškega značaja, saj je pisec podajal snov $\mathrm{v}$ kronološkem zaporedju in jo sistematično urejal $\mathrm{v}$ jasna poglavja. Tako je nastal enovit niz prispevkov kot pregled skladateljskih osebnosti in glasbenoslogovnih tokov 20. stoletja. ${ }^{40}$ Celotna snov je razdeljena na dva dela: $v$ prvem delu (predstavljata ga prva dva prispevka) je pisec orisal politično, socialno, znanstveno-tehnično in splošnoumetnostno situacijo prvih treh desetletij našega stoletja. Temu je dodal še pregled glasbenih slogovnih tokov in skladateljev. ${ }^{41} \mathrm{~V}$ drugem prispevku zaznamo znatno več piščevega entuziazma kot v prvem. Razlog je nedvomno v tem, da se je Šivic v tistem času začel glasbeno izobraževati in seznanjati z glasbo na Slovenskem, predvsem pa s pestrejšim in sodobnejšim evropskim glasbenim dogajanjem, ki ga je spoznal med študijem v Pragi. Medtem ko so

38 Gl.: Anton Trost - pianist in pedagog. GM 12 (1981/82) št. 8, str. 11.

39 Gl.: Tankočuten in ustvarjalen mož. GM 13 (1982/83) št. 2, str. 14.

40 GM je v svoj publicistični načrt vedno vključevala tematske sklope z najrazličnejšo tematiko: o slovenskih in svetovnih skladateljih, o glasbenih instrumentih, o različnih glasbenih žanrih in o posameznih glasbenih obdobjih.

41 V prvem, splošnejšem delu je Šivic obravnaval kompozicijsko usmeritev in dela R. Straussa, G. Mahlerja, M. Regerja, C. Debussija, M. Ravela, A. Skrjabina, B. Bartoka, L. Janačka, A. Schönberga in A. Berga, v drugem prispevku pa dela I. Stravinskega, P. Hindemitha, E. Kreneka, A. Honnegerja in A. Habe. 
komentarji uvodnega prispevka splošnejši, historični, pa lahko v drugem opazimo bolj oseben pristop. V njem se je Šivic osredotočil na slogovno usmeritev posameznih skladateljev in analitično pristopil $h$ kompozicijsko-tehničnemu načinu njihovih najbolj reprezentančnih skladb. Še pomembnejše pa je to, da se je posvetil drugi generaciji klasikov 20. stoletja, generaciji, kateri je, v primerjavi s prvo, na splošno namenjena manjša pozornost $v$ glasbeni literaturi. ${ }^{42} \mathrm{Ta}$ del poglavja je zanimiv tudi zato, ker iz načina pisanja razberemo tipiko Šivičevega razmišljanja o glasbi. Glede na to, da je bil v svoji glasbeni dejavnosti primarno skladatelj, vidimo, kako izrazito racionalno in analitično je obravnaval skladbe. Tako je $\mathrm{v}$ opisovanju stilnih usmeritev uporabljal strokovno terminologijo, iz analitičnega pristopa pa razberemo kompozicijsko-tehnično, racionalno dojemanje glasbenika praktika. Glasbo je opisoval s pojmi tehničnih postopkov, ki se tičejo konkretne kompozicijske izdelave in slušnega zaznavanja zvočnih pojavov, kot so npr. pokanje, brenčanje, kovinski zvoki, šumi, hitri tremolo, kromatični totali, rafinirani zvoki, curki šumov, zvočni sunki. Zanimiv pa je že kar nekoliko ciničen opis Schaefferjeve skladbe, ki je uporabljala "zvoke kot pri brisanju ali podobnih dejavnostih". ${ }^{43}$

Temu sklopu Šivičevih prispevkov lahko pripišemo visoko stopnjo didaktičnosti, piscu pa široko zgodovinsko razgledanost in objektivnost pri obravnanju snovi. To, da je v tem sklopu piščeva osebna nota prisotna le v manjši meri, je razumljivo, saj je tako izpolnil poučevalni namen prispevkov. Vendar pa tudi tu ne smemo prezreti komentarjev, ki so ključnega pomena za spoznavanje njegovega nazora. Ne glede na to, da je bil nenavadno široko dojemljiv za najrazličnejše in še tako sodobne usmeritve, pa primeri iz tega tematskega sklopa kažejo njegovo izjemno kritičnost; predvsem tam, kjer se mu je glasba zdela nesmiselna in estetsko neupravičena. Za Varesejevo glasbo, ki jo je raje imenoval zvočni pojavi, je priznal, da so jo "podbudile tehnična ostrina, hlad in togost" ${ }^{44}$ Največkrat ga je k takim zaključkom napeljala glasba Karlheinza Stockhausna. Poudaril je njegovo razvrednotenje estetskega in umetniškega $\mathrm{v}$ glasbi, saj "postane koncertni podij kraj nesmiselnega 'happeninga' " ${ }^{45}$ Netolerantnost do sodobnosti ni bila Šivičeva značilnost, pa vendar se je $\mathrm{v}$ tem primeru odzval $\mathrm{z}$ nedvoumnim komentarjem o estetski in eksistenčni upravičenosti Stockhausnove glasbe: "Višek šokantnosti? Višek samozavesti? Višek absurda?" ${ }^{46}$ Lahko bi trdili, da je bil Šivic med redkimi

42 Analitično in vrednostno so opisani skladatelji: A. Webern, E. Varèse, J. Cage, P. Schaeffer, K. Penderecki, G. Ligeti, M. Kagel in K. Stockhausen.

43 Gl.: Glasba XX. stoletja. GM 17 (1986/87) št. 4, str. 9.

44 Gl.: Glasba XX. stoletja. GM 17 (1986/87) št. 3, str. 9.

45 Gl.: Glasba XX. stoletja. GM 17 (1986/87) št. 6, str. 9.

46 Gl.: Večer s Stockhausnom. GM 5 (1974/75) št. 1, str. 12. 
sodobniki, katerih tolerančna meja za novosti je bila visoko postavljena. Vendar pa nam sledeči citat jasno razkrije, da je bila glasbeno vsebinska vrednost vseeno tista, ki je določala skrajno mejo njegove dojemljivosti: "Reakcija kritike in publike je zadržana in vprašljiva, ni možnosti primerjave in vrednostnih meril za to novo vrsto 'glasbe'. Sploh pa se postavlja vprašanje, ali gre sploh še za glasbo." ${ }^{47}$ Odgovor je preprost in iz njega sklepamo na nadaljnja Šivičeva estetska izhodišča in kritike. Dokler je bila glasba rezultat estetskega premisleka in intuicije, je bil njen zagovornik. Ko pa je "hrup postal glasbeni material", ${ }^{48}$ ko je glasba postala absurd, je Šivic svoje razmišljanje skrčil na suhoparne opisne pojme, v katerih pa ni našel več smisla, temveč le še oris glasbenozgodovinskih pojavov.

Za proučevanje Šivičevega publicističnega sloga in odnosa do glasbe je ves preostali opus v GM še tehtnejši, čeprav se s sodobno glasbo ni neposredno ukvarjal $\mathrm{v}$ nobenem od omenjenih poglavij. Ne glede na to, v kolikšni meri se prispevki navezujejo na osrednjo temo, iz posameznih komentarjev izvemo veliko več o glavnih točkah Šivičevih razmislekov. Njegove kritike koncertov nam ponujajo bogato paleto komentarjev o sodobnosti. Nekateri so dovolj racionalni, drugi že bliže dovtipom, $\mathrm{v}$ številnih primerih pa naletimo na pretirano zanesenjaštvo za sodobno glasbo. Več tolerantnosti, celo popustljivosti opazimo v kritikah simfoničnih koncertov orkestra RTV Ljubljana. Zdi se, da je Šivic marsikatero glasbeno pomanjkljivost spregledal zgolj zato, ker "so se simfoniki dostojno oddolžili domači tvornosti" ${ }^{49}$ Tudi kompliment k plošči, ki je "obogatila tisti del diskoteke, ki ga radi ponovno zavrtimo", ${ }^{50}$ je osamljen primer med recenzijami in je bil nedvomno posledica navdušenja nad sodobnostjo skladb Karla Pahorja, Paula Hindemitha in Franka Martina. Navedeni citati sicer niso negativno kritični, kažejo pa na Šivičevo osebno skladateljsko orientacijo. Še tako velika mera korektnosti nam namreč ne more prikriti njegove privrženosti ali odklonilnosti. Ni naključje, da je v recenziji med skladbami Haydna, Schuberta in Hindemitha poudaril, da je "ogrela" skladba slednjega ali pa, da je bilo zato ob poslušanju dveh skladb Petra Ebna "uživanje tem večje". ${ }^{11}$ Prav tako npr. skladbi Uroša Kreka sicer priznava "sodobnejši muzikalni izraz", ${ }^{52}$ vendar je s pojmi harmonija, ritmična enovitost in široka melodična zasnova izrazil svoje prepričanje, da je skladatelj sodobnejši, ne

47 Gl.: Glasba XX. stoletja. GM 17 (1986/ 87) št. 6, str. 9.

48 Gl.: Večer s Stockhausnom. GM 5 (1974/75) št.1, str. 12.

49 Gl.: GM $16(1985 / 86)$ št. 1 , str. 6.

50 Gl.: Orkester Slovenske filharmonije / RTV Ljubljana. GM 11 (1980/81) št. 2, str. 18.

51 Gl.: GM $18(1987 / 88)$ št. 3, str. 7.

52 Gl.: Jože Falout / RTV Ljubljana. GM 9 (1978/79) št. 8, str. 19. 
pa sodoben. Dovzetnejši je bil za "abstraktnega in s šumi nasičenega" Primoža Ramovša in njegova "sprotna presenečenja, tonske grozde in improvizacijske elemente". ${ }^{53}$ Največjo potrditev njegove dovzetnosti za sodobnost v slovenski glasbi razodeva naslednji citat: "Kdor si želi zdrave glasbe, polne življenjske radosti, si bo rad zavitel Sinfonietto." "T4 Tudi Lebičeve skladbe bi si želeli "še in še poslušati". Lahko rečemo, da sta ta dva skladatelja med Šivičevimi (mlajšimi) sodobniki edina, ki sta bila deležna njegovega skladateljskega priznanja. Zanimivo pa je to, da so Ramovševe skladbe njegovo pozornost vedno pritegnile le $s$ kompozicijskotehničnega vidika, nikoli pa ga niso, tako kot Lebičeve, napeljale $\mathrm{k}$ estetskim vprašanjem. Slednjemu priznava izjemno iznajdljivost in muzikalni lok, največji kompliment kot skladatelju pa je podal z besedami, da je znal "s skladbo [...] tudi nekaj povedati; nekaj, kar nas pritegne, zasvoji". ${ }^{56}$

Ob prebiranju Šivičeve publicistike zaznamo v njegovi osebnosti zapriseženega borca za uveljavljanje sodobne, predvsem slovenske glasbe. Njegova borbenost je ponekod tako močna, da jo je včasih uveljavil celo tam, kjer s samo idejo nima veliko skupnega. Tako je npr. lahko koncert pristransko ocenil z izjavo, da "spored ni segel niti v predklasiko niti čez romantiko". ${ }^{57}$ Tudi pripisu v recenziji posnetka Brahmsove 4. simfonije, da bo "ljubiteljem dobre glasbe plošča dobrodošlo kulturno razvedrilo", ${ }^{58}$ ne moremo pripisati velikega navdušenja. Podoben ironičen prizvok ima ocena simfonične sezone SF: "Doslej so bili [...] vedno osredotočeni na že uveljavljene klasične in romantične umotvore." 59 Včasih izjave preidejo celo $\mathrm{v}$ osebno prizadetost, kot npr. ugotovitev, da so $\mathrm{v}$ abonmajskem programu simfoničnega orkestra RTV Ljubljana "številčno najslabše zastopani slovenski skladatelji; jugoslovansko ime je eno samo". ${ }^{60} \mathrm{Da}$ je število neizvajanih, a kakovostnih skladb vedno večje, je bila njegova prepoznavna pripomba, saj je nenehno čutil zapostavljanje sodobnega repertoarja. Njegov konflikt s slovenskim glasbenim poustvarjalnim svetom se skriva za izjavami, kot je: "Domači umetniki pa naj se lotijo tudi tehtnejših skladb! Da ni primernih, je le jalov izgovor in potrditev nezanimanja zanje." ${ }^{161}$ Razumemo ga lahko kot nenehen apel slovenskim glasbenim institucijam, naj izvajajo slovenske sodobnike, torej tudi njega samega.

53 Gl.: ibid.54 Gl.: Primož Ramovš / RTV Ljubljana. GM 11 (1980/81) št. 4, str. 19.

55 Gl.: Lojze Lebič: Queensland Music / Simfonija z orglami / Atelje III (ZKP RTV Slovenija, 1994). GM 24 (1993/94) št. 6, str. 19.

56 Gl.: Lojze Lebič: Queensland Music / Simfonija z orglami / Atelje III (ZKP RTV Slovenija, 1994). GM 24 (1993/94) št. 6, str. 19.

57 Gl.: Mladi mladim. GM 18 (1987/88) št. 2, str. 7.

58 Gl.: Dvakrat ZKP RTV Ljubljana. GM $16(1985 / 86)$ št. 8, str. 21.

59 Gl.: Ljubljanska simfonična sezona. GM 23 (1992/93) št. 3, str. 2.

60 Gl.: Obeti ljubljanske glasbene sezone. GM $10(1979 / 80)$ št. 2, str. 3.

61 Gl.: Poletni festival Križanke. GM 17 (1986/87) št. 1, str. 2 - 3. 
Zdi se, da je Šivic hotel in tudi je ob vsaki publicistični priložnosti dodal svojo misel o sodobni glasbi, pa čeprav se zdi v nekaterih primerih pretirana. V poročilu festivalske prireditve je popolnoma neprimerna in odvečna pripomba, da "se že pri koncertih velikih orkestrov kaže negativen odnos do sodobnejšega sporeda" . ${ }^{2}$ V nekaterih primerih je Šivic premalo upošteval ozadje nekega glasbenega dogodka, pa vendar je umestno opozarjal, da zaradi svoje programske naravnanosti ljubljanski Festival ni najbolj primerno služil promociji in popularizaciji naše domače literature ter reprodukciji sodobnega ali manj znanega repertoarja.

V GM se Šivic ni neposredno ukvarjal z glasbenoestetskimi vprašanji, saj so presegala njegove zadolžitve pri reviji. ${ }^{63}$ Seveda pa se je $\mathrm{v}$ prispevkih posredno dotaknil tudi umetniške vrednosti glasbe in njene emocionalne vsebine. Iz takih zaznamkov lahko enakovredno prepoznamo njegov estetski nazor. Največkrat se nanašajo predvsem na kritike koncertov in so posledica reakcij poslušalcev, ki so ravnodušni do dobrega ali slabega, pasivni do sodobnega ter navdušeni nad že znanim, klasicističnim, romantičnim in pompoznim. Zaradi tega se ni čudil, "da so najbolj navdušile pesmi v ritmu koračnic". ${ }^{64} \mathrm{Kljub}$ temu, da je imel Šivic vrednostno dobro izostren okus in si ni zatiskal oči pred malomeščanskimi in komercialnimi elementi glasbene ponudbe in povpraševanja, pa ga je vseeno zaneslo $\mathrm{v}$ utopično nerealnost: "Osveščen poslušalec čuti, kje in kdaj se za zvoki skriva umetniška vrednota, čeprav se to registriranje zlepa ne da opisati ali dokazati." ${ }^{165} \mathrm{Iz}$ dosedanjega opisa sledi, da je bil Šivic strog, strokovno opredeljen in kritičen poslušalec. $\mathrm{Pa}$ vendar moramo racionalnemu polu njegove osebnosti enakovredno pridružiti še tisto značilnost, ki je med vsemi najpomembnejša: njegov čisti muzikalni in emocionalni odnos do glasbe. Kot modernistu mu ni bilo težko sprejemati še tako ekstremnih glasbenih pojavov, vendar ga je morala glasba prvinsko, emocionalno nagovoriti, da je pridobila njegovo odobravanje: "Naj bo glasba po zvoku in sestavi kakršnakoli, v vsakem primeru ostane le nepomemben hrup, če se ne dotakne sprejemajočega duha. ${ }^{" 66}$ Čeprav mu v številnih kritikah lahko očitamo pristransko zagovarjanje svojih osebnih preferenc, je vseeno obdržal potrebno objektivnost glasbenega esteta. Njegovo čisto muzikalno naravo najbolje izpričujejo izjave, s katerimi je najpogosteje opisoval svoje vtise o interpretacijah: živ utrip, plemenit zanos, logična muzikalna linija, intenzivno podoživljaje glasbene vsebine, očarljiva zvočnost, umetniško pretehtan izraz.

62 Gl.: Odmevi z mednarodnega Festivala Ljubljana. GM 18 (1987/88) št. 1, str. 2.

63 V Grlici so bila zaradi pedagoškega namena revije v pretežni meri prisotna vprašanja o estetiki glasbe, njeni umetniški in vzgojni vrednosti.

64 Gl.: O koncertnem občinstvu. GM 24 (1993/94) št. 6, str. 3.

65 Gl.: GM 18 (1987/88) št. 3, str. 7.

66 Gl.: ibid. 
Analitičen prerez prispevkov Pavla Šivica v Glasbeni mladini nazorno razkriva umetniško in intelektualno osebnost, ki je bistveno in izrazito zaznamovala celotno slovensko glasbeno življenje. Skladateljsko delo je štel $v$ vseh fazah lastnega umetniškega dozorevanja za primarno. Ob tem se je zavedal tiste skladateljske zaprtosti v slonokoščeni stolp zunaj sočasnega glasbenega dogajanja in sprotnega reagiranja nanj. Pisanje o glasbi, predvsem za glasbeno manj izobražen krog bralcev, je štel kot samoumevno moralno dolžnost do občinstva in kot edino možno sredstvo za vcepljanje obče glasbene zavesti na Slovenskem. V tem pogledu je častno nadaljeval publicistično dediščino Slavka Osterca, v pisanju, namenjenemu izključno mladini, pa jo je nagradil s pristnim profesionalnim zanosom. Obsežna bibliografija člankov priča, da je Šivic vtisnil izrazit pečat slovenski kritiki svojega časa. V to dejavnost se je vključil v tridesetih letih, ko je slovenska kritika že gradila na temeljih Marija Kogoja in Slavka Osterca in poskušala posodobiti naziranje o glasbi med najširšim slojem prebivalstva.

V kritiškem poklicu je Šivic ostal neprekinjeno vse do svoje smrti; deloma se je zavedal, da je s publicistiko našel neposredni stik $s$ poslušalci in vpliv na njihovo samostojno razpoznavanje glasbenih vrednot, deloma pa si ni delal utvar, da je slovenska glasbena kritika v njegovem času že dosegla raven strokovno zanesljivega medija. Šivičev mladostniški kritiški slog je bil oster, strog in nepopustljiv, v posameznostih celo spodbudno ironičen. Uravnovešeno razmerje med kritičnim in racionalnim ter emocionalnim in glasbeno-estetskim je postalo osrednje v Šivičevi publicistiki.

V začetku sodelovanja pri Glasbeni mladini opazimo, da se je Šivic približeval vzgojni namenskosti revije, sčasoma pa je v pisanju postal do mladih bralcev bolj zahteven in "odraslo" vzgojiteljski. Od takrat je pisal v čistem glasbenokritiškem slogu, ki ni zanemarjal ne zunajglasbenih okoliščin ne sociološkega ozadja. Prebiranje njegovega publicističnega dela sodi v natančne umetniške in človeške podobe Pavla Šivica kot celovite in samosvoje glasbene osebnosti. Izraziti sta predvsem dve potezi Šivičeve glasbene osebnosti. V kritikah je dajal absolutno prednost umetniški, estetski resnici glasbe. Zato je bil toliko bolj ogorčen, ko je naletel na vsesplošno potvarjanje glasbenega okusa $v$ družbi in programski politiki. Tu je mestoma zašel tudi v idealiziranje; predvsem si je - žal utopično - želel, da bi sodobna (seveda tehtna) glasba dobila svoje odmerjeno in zasluženo mesto $\mathrm{v}$ vseh glasbenih medijih. V tej svoji sodobniški prizadevnosti je bil tako vnet in borben, da je to pogosto zasenčilo nekatere posameznosti o predmetu, o katerem je pisal. Druga močna poteza njegove glasbene osebnosti je bila doslednost pri vrednotenju; vedno in v vseh glasbenih funkcijah, ki si jih je nalagal, je Šivic nastopal kot zagovornik glasbene estetike in $\mathrm{v}$ človeškem življenju $\mathrm{z}$ ničemer drugim nadomestljive duhovne vrednosti. $\mathrm{V}$ tem pogledu ni poznal nikakršne omahljivosti, črpal je iz lastnega duha. Svojih osebnih pogledov prepričanja ni nikoli 
skrival, a tudi vsiljeval jih ni. Izrazi, s katerimi je Šivic opisoval interpretacije ali skladbe same, govorijo to, da je glasbo dojemal kot estetsko in emocionalno življenjsko sopotnico slehernega človeka. Na občutek intuicije se je popolnoma zanašal, nanj pa zgradil kritiko z vsem širokim splošnim in glasbenim znanjem, nenehnim izobraževanjem in izkušnjami. Polemičnega duha v Pavlu Šivicu ni bilo veliko, tem večje pa je bilo demokratično stališče o vprašanjih glasbe in poustvarjanja. Ne glede na svoje usmeritvene preference je spoštoval in upošteval drugačnosti, četudi so se razlikovale od njegovega stališča.

Šivic je živel in deloval v obdobju, ki je bilo v slovenski glasbeni zgodovini precej razvejano. Izoblikovane so bile že vse oblike glasbenega dela - od kritike, revialne literature, pedagogike do glasbenega založništva. Kljub temu je bilo malo glasbeno tako vsestranskih izobražencev medvojne in povojne generacije, sploh pa skladateljev, ki so se kvalitativno in kvantitativno enakovredno ukvarjali tudi s publicistiko.

Kritiško delo v Glasbeni mladini zaradi namenskosti revije daje dober vpogled v idejni in nazorski svet Pavla Šivica. Jasno je razpoznavna slogovna razlika med kritikami in recenzijami. Čeprav so slednje prav tako ocene, pa zahtevajo povsem drugačen pristop. Njegova pomembneǰ̌a osebna poteza je korektnost, ki jo še najbolje razberemo iz biografskih prispevkov. Ne glede na delež osebnega pristopa, je zavestno skrbel za objektiven način pisanja. Še več, njegov slog je oplemeniten $s$ humorjem, številnimi dovtipi in anekdotami. Pri ugotavljanju, kako in v kolikšni meri se skozi publicistično delo lahko kaže osebni odnos do snovi, moramo upoštevati Šivičevo primarno, torej skladateljsko usmeritev. Tako se je tudi v publicistiki Glasbene mladine najpogosteje izrekal za sodobnost. Prav v tem neumetnostnem kriteriju lahko najbolje uvidimo in razpoznamo njegov estetski in umetnostni nazor. V svojih prispevkih je nenehno opozarjal, da sodobni glasbi namenjamo premalo pozornosti: tako $\mathrm{v}$ programski politiki glasbenih institucij, $\mathrm{v}$ sporedih posameznih interpretov kot $v$ pedagoškem načrtu. Šivic je imel zelo dober vpogled $\mathrm{v}$ glasbeno literaturo, zato je s pravo virtuoznostjo in vehementno rutino ocenjeval najrazličnejše snovi. V svoji vsestranskosti pa je bil vedno sodobnik, naj je šlo za slovensko ali svetovno glasbo, in estet, naj je šlo za preteklo glasbo ali glasbo popolnoma ekstremnih usmeritev. Med Šivičeve posebnosti pa gotovo štejeta dve: v slovenski glasbi dragocena in prav redka humoristična poanta ter izrazita zavest o nujno potrebni kontinuiteti poštene glasbene kritike. 


\section{Publicistic and Critical Style of Pavle Šivic in Musical Youth (1974-1995)}

\section{Summary}

Pavel Šivic emerged as a publicist in a period when in Slovenia all forms of musical life were already in progress. Still, in addition to bis activity as a composer, a musical teacher, and a concert performer, be was one of the few who in the inter-war and post-war periods in terms both of quality and output deserved credit also as a musical journalist. The present contribution deals only with a part of bis publishing opus; it is concerned with bis two decades long co-operation (1975-1995) at Glasbena mladina (Musical Youth) and is focused on establishing the main features of Šivic's style as a publicist and at the same time identifies his aesthetic and artistic views. Despite the broad the matic palette the greatest expressiveness is achieved through his attitude towards contemporary trends in music and his aesthetic aspect. Sivic thus clearly stands out as a widely reflecting and critical personality, with a rational discernment of the aesthetic values in music, but primarily led by sense of intuition. The influence of Sivic's contemporary orientation in bis compositional work is reflected also in bis work as a publicist; in this would-be contemporary endeavours be has been so ardent that this has infrequently even overshadowed a necessary degree of objective evaluation. Despite bis true many-sidedness be has invariably remained an advocate of what is contemporary - be it in Slovenian or in world music - and an aesthete, either as regards music from the past or music of completely extreme orientations. 